DOI: $10.17805 /$ trudy.2016.4.2

\title{
ДЕСЯТЬ ТЕЗИСОВ О ВОЙНЕ КАК СПОСОБЕ РЕШЕНИЯ ЧЕЛОВЕЧЕСКИХ КОНФЛИКТОВ
}

\author{
А. А. Королев \\ (Московский гуманитарный университет)
}

Аннотация: В статье характеризуются основные черты войны как способа решения человеческих конфликтов.

Подготовлено на основе доклада автора на Всероссийской научной конференции «Военная история России», которая прошла в Московском гуманитарном университете 25 апреля 2016 г.

Ключевые слова: война; конфликты; агрессия

\section{TEN THESES ON WAR AS A CONFLICT RESOLUTION METHOD}

\author{
A. A. Korolev \\ (Moscow University for the Humanities)
}

Abstract: The article, based on the paper the author delivered at the conference on the military history of Russia held at Moscow University for the Humanities on April 25, 2016, summarizes the most important points of warfare as an instrument of conflict resolution.

This article is based on the paper presented at "The military history of Russia" conference, which was held at Moscow University for the Humanities on April 25, 2016.

Keywords: war; conflicts; aggression

Первый тезис: Что такое война? Обратившись к толковому словарю С.И. Ожегова, узнаем, что это вооруженная борьба; враждебные отношения с кем-то (Ожегов, 1982: 84).По классическому определению Карла фон Клаузевица, немецкого военного теоретика первой половины XIX века, «... война естьне что иное как продолжение государственной политики иными средствами» (Краузевиц, 2002: 11).Он указывал на двойственность метода (цели) ведения войны. Во-первых, сокрушение врага, т. е. его политическое уничтожение или, во-вторых, некоторые завоевания у границ своего государства, чтобы удержать их за собою или же воспользоваться ими как полезным залогом при заключении мира (там же: 10-11). Далее 
он подчеркивал, что война - это «акт насилия, имеющий целью заставить противника выполнять вашу волю» (там же: 23).

Ежегодно в мире происходит примерно три десятка военных конфликтов, которые называют нередко «малыми войнами». Почему они возникают? Причины разные: территориальные споры, захват источников сырья, ресурсов, воды, этнокультурные и межрелигиозные конфликты, застарелые межгосударственные противоречия, которые не решаемы годами и десятилетиями. Только Советский Союз и Россия после Второй мировой войны участвовали в 49 конфликтах. Примечательно: только в Сирии мы участвовали 6 раз. Последнее использование вооруженных сил (военно-космических сил преимущественно) началось в 2015 г. и продолжается поныне. Мотивы участия: уничтожить террористов за рубежами нашей страны, пока они не оказались на ее территории.

Отложенные (замороженные) конфликты после распада СССР произошли в Абхазии (1992 г.), Приднестровье (1992 г.). Вооруженный конфликт в Таджикистане в начале 1990 -х годов привел к гражданской войне, погибло несколько сот тысяч человек. Серьезный конфликт произошел в 1991-1994 гг. между Азербайджаном и Арменией из-за Нагорного Карабаха, территории, населенной армянами. В апреле 2016 г. спор между двумя государствами привел вновь к кровопролитию.

Для справки: в настоящее время около 50 стран ведут территориальные споры. В Африке - 20 споров, в Европе - 19, на Ближнем Востоке - 12 и в Латинской Америке - 8 (Бернацкий, 2015: 262). Примечательно, что почти половина бывших союзных республик предъявили территориальные претензии России после распада Советского Союза. Среди них Украина, предъявившая права на Смоленскую, Белгородскую и другие области.

Второй тезис: «страсти правят миром, являются движителем войны». Если предпринять человеческое измерение войны, то следует говорить, прежде всего, о психологической составляющей, о глубинных основах отношения человека (группы людей), племен, народов к себе подобным, но чужакам. До сих пор в современной жизни срабатывают архетипы подсознания, которые корнями уходят в седое прошлое, в неандертальскую эпоху. Один из них выражается как «они» и «мы». Мы - «хорошие», они «плохие», по сути - враги. Кроме того, людям имманентно присущииррациональные страсти такие, как «жажда крови» и «жестокость» (К. Лоренц).

Эрих Фромм, исходя из этого, предполагает, что «причины войны коренятся в жажде убивать, т. е. что войны обусловлены врожденной склонностью человека к разрушению» (Фромм, 2004: 9).

При этом Э. Фромм выделял два вида агрессии: 1) как биологически необходимую, которая направлена на то, чтобы сохранить свою видовую принадлежность. Человек при этом либо убегал, либо нападал. Эту агрес- 
сию ученый назвал «не злонамеренной», и 2) «злонамеренную, злокачественную», человеческую деструктивность. В этом случае он имел в виду «специфически человеческую страсть к абсолютному господству над другим живым существом и желание разрушать...» (там же).

Поэтому неизвестно, чего больше в войнах рационального (разработка стратегии и тактики, военных операций на поле боя и т. д.), чем иррационального, мистического, деструктивного. Люди с сильной харизмой, оказавшись на вершине власти, втягивают свои народы в разрушительные войны. Примеров несть числа: Наполеон, Гитлер. 3. Фрейд даже отказался участвовать в движении борцов за мир, т. к. считал войны неизбежным следствием периодических вспышек человеческой агрессивности (Война, Электр. ресурс).

Третий тезис: терминологический. Война - междисциплинарная проблема для изучения. Поэтому не следует ограничиваться только осмыслением этой категории через призму исторической и общей психологии. Развитие социогуманитарных наук в последние годы обозначило актуальность разработки базовых категорий и понятий, которые носят межпредметный, системный характер. Эти базовые опорные понятия дают возможность вскрыть бесконечное множество связей и опосредований человеческих потенций и интенций, которые отражают духовнообщественные реалии. К таким репернымкатегориям следует отнести категорию войны. Войны изучаются с разных сторон: военной наукой, социальной, философией, экономикой, статистикой демографией.В постперестроечное время заговорили о демографической войне, которую Запад (ведущие его страны) ведут против России. Так, в настоящее время наша страна подвергается беспрецедентной атаке бесполых. Налицо стремление превратить человека в третий пол, говоря словами 3.Фрейда, в «оно», сделать героем трансвестита - победителя «Евровидения», бородатую женщину КончитеВурст. Видимо, западная элита, усиленно пропагандирующая однополые браки (в которых есть «родитель № 1 » и «родитель № 2»), начисто лишилась инстинкта самосохранения либо включилась в борьбу за доведение человечества вместо 7,5 млрд людей, населяющих планету, до «золотого миллиарда». Что это как не воплощение идей современных мальтузианцев о том, что земных ресурсов всем не хватит? Да здравствуют избранные - выходцы из 20 ведущих стран Запада?!

Тезис четвертый - типологии войны. Существуют десятки типологий, в основу которых берутся различные признаки. Начну, как говорят англичане, «lastbutnotleast» (последняя по счету, но не последняя по значению), с типологии по ощущению: «горячая война», «холодная война» и «прохладная война». Последнюю войну известный философ и социолог А.А. Зиновьев применил к современному периоду. Есть две точки зрения 
по поводу холодной войны: 1) в холодной войне победил Запад, 2) Запад не победил, просто Россия как наследница СССР вышла из противоборства двух блоковых систем.

Есть и противоположные мнения. 1) Холодная война, на которую Америка потратила 3,5 триллиона долларов, закончилась в 1991 г. 2) Холодная война не закончилась. Под редакцией И.М. Ильинского вышла книга под характерным названием: «Идет война холодная» (Идет война ..., 2015). Ему вторят политики К. Н. Бабиченко и Д. З. Мутагиров (Бабиченко, 2016; Мутагиров, 2016). Развивая мысль о том, что холодная война не прекратилась, второй автор утверждает, что она является перманентным явлением в жизни человечества и образования государств. Соответственно, холодная война может прекратиться только после прекращения деления мира на соперничающие между собой государства и складывания универсального сообщества свободных и равноправных людей и народов. Первый автор исследует феномен дискурсивной войны на примере правозащитного фронта. Опираясь на широкий круг источников, он освещает процесс искажения и военизации концепции прав человека. Завершают статью выводы о способности России противостоять международному давлению. Предлагается использовать опыт Израиля успешной обороны против дискурсивных и политических агрессий.

Следующая типология - по признаку территориальности: существуют 1) мировые войны, 2) региональные, 3) локальные войны.

Определенный интерес вызывает типология, во главу угла которой положен технологический признак. По мнению ряда военных ученых, существовало шесть видов войн за всю историю человечества. Первый, когда в качестве орудия убийства использовали подручные средства палки, камни, а также стрелы,копья и ножи, до шестого вида, когда предполагается использование орудия убийства космического базирования, так называемые«звездные войны». Между прочим, Президент США Рейган ввел в заблуждение военно-политическое руководство СССР о том, что Америка приступила в практическом плане к подготовке «звездной войне». Это привело к беспрецедентной гонке вооружений, к обескровлению советской экономики.

В период, когда шли войны четвертого вида (это Вторая мировая война), широко применяли машины. К пятому виду специалисты причисляют войну США и ее союзников против Сербии в 1999 году. Использовались некоторые элементы космических войн, в частности, спутниковое наведение для удара с воздуха и земли.

Шестой вид войны связан с использованием космического оружия.

Пятый тезис - «звездные войны». Международное сообщество в лице здравомыслящих людей крайне озабочено милитаризацией космоса, воз- 
можным использованием космического пространства в военных целях. Советский Союз выступил лидером в освоении космического пространства. Это остается фактом. Но жизнь не стоит на месте. Америка ответила на вызов страны Советов - высадила человека на Луну, затратив 30 млрд долларов. Это равно финансированию всего сельского хозяйства Советского Союза. В период перестройки после распада СССР страна стала терять свои преимущества по освоению космоса. Только в последние несколько лет руководство России озаботилось возрождением космической отрасли. По заявлению Президента РФ В. В. Путина от 27 апреля 2016 г., ракетная отрасль развивалась более быстрыми темпами, чем другие отрасли народного хозяйства. Был введен в строй новый космодром «Восточный» в Амурской области (шестой по счету).

Оттуда стартовала первая космическая ракета. Военно-политическое руководство осознает, что милитаризация космоса - угроза национальной безопасности страны. Космос уже буквально нашпигован космическими аппаратами. Только одних спутников (значительное число которых являются спутниками-шпионами) насчитывается почти 1000. Из них 40\% принадлежит США. Годовой космический бюджет США составляет примерно 36 миллиардов долларов. Это 73\% от всей суммы, которую страны мира (а их 115) расходуют на освоение космоса, в том числе Россия, Китай, Европейский союз, Индия и Япония (Бернацкий, 2015: 287).

В арсенале космического оружия - противоспутниковые системы, ракеты с термоядерными боеголовками, которые курсируют на разных орбитах. По команде с земли они могут нанести удар на заданные территории. Очень острым является вопрос о создании постоянных орбитальных военных баз. «Ястребы» из Пентагона мечтают о создании военных баз на Луне, использование в военных целях космических тел - астероидов и т. д.

Шестой тезис - «иибридные войны». Новое слово в военной науке гибридные войны. Этот термин появился в конце XX века в США и не имеет однозначной трактовки. Так, «Википедия» дает такое определение: это - «понимание военной стратегии, объединяющей в себе как единое целое обычную войну, малую войну и кибервойну», «единство действий с применением ядерного, биологического и химического оружия, самодельных взрывных устройств и средств информационных войн» (Гибридные войны, Электр. ресурс).

Если использовать образ, то гибридная война как «матрешка». При ее разборке можно увидеть разные части, т. е. разные виды войны. Но в отличие от вертикального принципа, по которому делается «матрешка», гибридная война имеет и горизонтальный срез: разновидности войн взаимопроникают друг в друга, взаимодействуют друг с другом. 
По мнению С. Сулакшина, известного политолога, «гибридная война - это тип военного противостояния государств, вовлекающий в вооруженные действия, помимо регулярной армии или вместо регулярной армии, спецслужбы и спецмиссии, наемные силы, партизанские силы, массовые протестные беспорядки, террористические атаки, при этом целью гибридной войны может являться не оккупация, но смена политического режима или государственной политики в атакуемой стране (Гибридная война, Электр. ресурс).

Профессор В. Багдасарян отмечает, что «гибридная война» вроде бы и не война, а вместе с тем война, скрещивающиеся понятия, характерные для постмодерна. Что касается событий на Донбассе, то парадигма трактовки гибридной войны меняется. Здесь она - это уже не смесь различных тактических приемов, это фактическая война без прямого объявления войны, без прямого участия. Дискурс поменялся, и этот дискурс используется акцентировано против российской позиции (там же). При моделировании и планировании «гибридных войн» нельзя недоучитывать опыт решения проблем сложности в военном деле в западном мире, в частности в США. Здесь проблему сложности изучает Институт Санта Фе, Группа по анализу действий в условиях неопределенности, Центр умной обороны, Центр по исследованию сложных операций при Пентагоне и Университете национальной обороны США.Разработки в области методологии управления многофакторными системами, нелинейной динамики уже почти 20 лет использует Корпус морской пехоты (Неклесса, 2016).

Член верхней палаты парламента Нидерландов, экс-советник по безо-пасности при НАТО, генерал-майор в отставке Франк ванКаппен убежден, что в противостоянии с Украиной Россия применила новый метод ведения войны - гибридный. Важное место в своем анализе он отводит геополитическому фактору, опираясь на проведенное по заказу НАТО исследование MultipleFutures. Согласно одному из сценариев, на фоне слабого разделенного во мнениях международного сообщества станет возможным возвращение к политике образца XIX века, когда сильные государства будут навязыватьсвою волю слабым государствам, потому что международное сообщество, которое могло бы приструнить подобное поведение, фактически отсутствует. По мнению отставного генерала, ни Украина, ни остальные страны, оказавшиеся на линии соприкосновения геополитических платформ, не имеют возможности самостоятельно выбирать свою судьбу, они зажаты между российской сферой влияния с одной стороны или европейской - с другой. Сегодня линия среза, которая проходила через Польшу (оглянитесь на историю этой страны за минувший век), Венгрию, Чехословакию, сместилась на восток и проходит через Украину, через Беларусь, Молдавию и Грузию. Франк ван Каппен 
утверждал, что «Америка и Европа вечно будут продолжать кричать, что они переход Крыма к России не признают, то есть это будет очередной замороженный конфликт». Он указал на одну важную отличительную черту гибридной тактики ведения войны: мировое сообщество ставится перед свершившимся фактом. Мировому сообществу остается говорить: «Мы этого не признаем», но факт присоединения уже свершился. В краткосрочной перспективе это очень выигрышная тактика: «Смотрите, что у меня получилось! Без единого выстрела!» Западный политик имел ввидуприсоединение Крыма к России в 2014 году. В долгосрочной перспективе Путин проиграет. Россия будет попадать во все большую зависимость от зарубежных технологий и капитала, окажется зажатой между двумя мощными экономическими блоками - трансатлантическим блоком США и EC, который формируется сейчас и будет насчитывать свыше 800 миллионов жителей, и Китаем. Между тем, «Западу вовсе не выгодно иметь под боком нестабильную, враждебно настроенную «бедную Россию» (Генерал Франк ..., Электр. ресурс).

Седьмой тезис - «мягкая сила» как составная часть информационнопсихологической войны. Война образов. «Мягкая сила» (авторство термина принадлежит американскому политологу, бывшему заместителю министра обороны США Джозефу Наю) является антитезой «жесткой силе», включающей в себя применение и летального оружия.

Говоря о множественности контекстов, которые задаются различными целями (существует так называемое «древо целей»), следует сказать, что указанный контекст входит в такой конструкт, как «информационнопсихологическая война».

Если обратиться к концепции «мягкой силы», то ее автор - неолиберал считает, что это «способность добиваться желаемого на основе добровольного участия союзников, а не с помощью принуждения и подачек». Он считает, что в мире три главных силы - армия, экономика и «мягкая сила». В конце XX века американский ученый разделил возможность государств на две категории: на «жесткую силу» (hardpower) и «мягкую силу» (softpower) - популярную силу.

В России к использованию концепции «мягкой силы» в практическом плане высшее политическое руководство обратилось в начале второй декады XXI века. В. В. Путин, выступая на совещании послов и постоянныхпредставителей РФ в июле 2012 г. указывал: «Политика “мягкой силы” предусматривает продвижение своих интересов и подходов путем убеждения и привлечения симпатий к своей стране, основываясь на ее достижениях не только в материальной, но и в духовной культуре, и в интеллектуальной сфере. Пока надо признать, образ России за рубежом формируется не нами, поэтому он часто искажен и не отражает реальную ситуацию ни 
в нашей стране, ни ее вклад в мировую цивилизацию, в науку, культуру, да и позиции нашей страны в международных делах сейчас освещаются как-то однобоко» (Совещание послов ..., 2012: Электр. ресурс).

Для формирования положительного имиджа современной России и продвижения ее интересов на международной арене, для использования «мягкой силы» создана специальная структура - Федеральное агентство по делам СНГ, соотечественников, проживающих за рубежом, и по международному сотрудничеству - Россотрудничество.

В плане «мирного» наступления имеется широкий спектр способов, приемов воздействия на общественное мнение как друзей, партнеров, так и недругов, обывателей, которых предостаточно в любой стране. Нередко последние решают исход политических (выборных) кампаний, отражают симпатии и антипатии. Их легко запугать, если вести массированную пропаганду с использованием пси-оружия, которое действует на подсознание, минуя волевую (рациональную) сферу.

В арсенале политики «мягкой силы»: распространение сведений о стране, ее достижениях в области науки, культуры, искусства; обучение иностранных студентов; инициирование гуманитарных акций; усиление информационного ресурса через СМИ, социальные сети и т.д.

Негативный образ России в наши дни «лепится» глазами, как наших соотечественников, так и зарубежных представительных людей. Причем мотивы у них разные. В России это бывшие диссиденты, например, Сергей Ковалев, «узник совести», ставший правозащитником, который обращался к Западу, чтобы наказать современную Россию, которая развивалась не по его предначертанию. Это и известный русский писатель Александр Солженицын. Были в свое время у него свои мотивы внести черную краску в оценку самого святого подвига в России - СССР - Великой Отечественной войны. Хотел он или субъективно не хотел, но ВОВ для него «бездарно выигранная война» (Сергей Кара-Мурза, Электр. ресурс).

По справедливому замечанию публициста Сергея Кара-Мурзы, война для национального самосознания является обобщенным символом, она не втискивается в рамки классовой борьбы, что нападки на нее - часть большой психологической войны против России (там же). Это и бывший руководитель правительства Михаил Касьянов («Миша-2»), который посетил Америку в качестве руководителя оппозиционной (непарламентской) партии. Задача визита, чтобы руководство Штатов «давило» на Путина с целью изменения политики.

Обратимся к взгляду на Россию и русских из-за океана. Этот образ подается в научных понятиях и категориях психоаналитики. Американский исследователь Д. Ранкур-Лаферьер, задавшись поиском ответа на извечный вопрос о загадочной природе русской души, ответ, на который иностранные наблюдатели стремились дать несколько столетий. Из-под 
его пера появлялся образ «России - матери», слитый с коллективом, что это выливается в такие черты русского характера, как инфантильность, безответственность, готовность подчиняться властям, идти на страдания и вести себя в пораженческой мазохистской манере. Американский психоаналитик договорился до того, что именно нравственный мазохизм и является той самой загадкой русской души.

Оказывается, что, по Ранкур-Лаферьеру, в отличие от «женского образа» России страны Запада ассоциируются в массовом сознании русских с чисто «мужским» образом и поэтому представляют угрозу для «матушки - России». Такое восприятие русских автор видит в параноидальном характере русского мышления и склонности к нарциссизму. Это приводит к различным фобиям в отношении США, Западных государств в целом. Вот вам и антиамериканизм и неприемлемость расширения НАТО на Восток?! (Верлина, 2003).

На постсоветском пространстве в последние два года активно в войну образов включилась по известным причинам Украина. По справедливому замечанию языковедов, на Украине высмеивание и пародирование, причем очень злое и ядовитое, имеет давние корни, лежит в основе национальной культуры. Характерно, что первым произведением, написанном на литературном украинском языке, считается поэма Ивана Котляревского «Энеида», представляющая собой пародийную перелицовку одноименной античной поэмы Вергилия. Главный герой, например, оказавшись в Карфагене, начинает «мутить как на селе москаль» (Мирютин, 2015).

В связи с присоединением Крыма к России в украинской массовой культуре созданы типажи и образы, призванные развенчать как конкретных, так и типичных лиц. Так, Наталья «Няш-мяш» Поклонская подается как сексуальная женщина-прокурор с лицевым дефектом, заработанным, по слухам, в конфликте с бандитской группировкой. Бесстрашный обвинитель, в лапы которого, тем не менее, тайно мечтает попасть любой преступник. «Казак Бабай» - бородатая русская экзотика в моднейших очках, крейзи-рашен, от скуки отправившаяся завоевывать русские земли, сбивающий вертолеты чуть ли не из рогатки и сдержанно танцующий на городском празднике в Краматорске, проходящем на фоне военных действий (Война образов: Электр. ресурс).

Примечательно, в ходе противостояния в Донбассе та и другая сторона использовали военные реликвии - символы различных эпох. Ополченцы взяли на вооружение тяжелый танк ИС времен Великой Отечественной войны, а украинская армия - броневики Первой мировой войны, не представляющих никакой военной ценности. Этот факт был призван показать, что последняя применяет всевозможные средства, в том числе музейные бронемашины, оснащенные пулеметами «Максим». 
Украинские идеологи-националисты стремятся выкорчевать из национального сознания опорные понятия и персоналии, связанные с советскими реалиями. Мощным валом прокатилось по стране крушение памятников Ленину и другим представителям Советской власти. Обнародован список имен к украинскому закону о декоммунизации. Институт национальной памяти Украины объясняет принцип отбора так: «Этот список лиц, которые занимали руководящие должности в коммунистической партии, высших органах власти и управления СССР, УССР, других союзных и автономных республик, сотрудники ЧК-ГПУ-НКВД-КГБ, деятели Октябрьского переворота 1917 года».

Так же под декоммунизацию попадают те, кто устанавливал советскую власть на Украине, преследовал участников борьбы за независимость Украины в XX веке.

Поражаешься вольной фантазии составителей списка. Здесь наряду с Лениным, Марксом и Энгельсом соседствуют рядовые «участники установления советской власти на Донбассе»- Яков, Сафрон и Савелий Аникеев. В списке значится прославленный шахтер Алексей Стаханов, Демьян Бедный («агитатор в частях большевистских войск»), Аркадий Гайдар («член компартии, член ЧК»). Запрещены писатели Александр Фадеев («участник борьбы с космополитизмом»). Заодно запрещен Василий Чапаев, Анри Барбюс («член компартии и автор формулы «Сталин - это Ленин сегодня»).Вне закона оказался литературный герой Павел Корчагин, а также Генсек ЦК КПСС Леонид Брежнев. Среди запрещенных оказались... Валентина Терешкова. (Принимала участие в событиях оккупации Крыма Россией в 2014 году) (Вяхирев, 2015).

Тезис восьмой - «Современное оружие - новые угрозы».

Военно-техническая мысль не стоит на месте. В оборонном арсенале ряда государств появились другие не менее разрушительные виды оружия, такие как геофизическое (тектоническое), вакуумное, генетическое и др.

Последствия применения геофизического оружия катастрофичны: многочисленные жертвы и разрушения в городах и селах, которые оказались в зоне бедствия. Так, ядерные испытания в Неваде вызвали сильное землетрясение в ряде стран Латинской Америке. В узбекском поселке Газли в 1976 и 1984 годах произошли мощные землетрясения, как полагают специалисты, вследствие испытаний ядерного оружия на семипалатинском полигоне (Казахстан) (Бернацкий, 2015: 279-280).

Механизм использования вакуумного оружия таков. На боевую позицию доставляется авиацией либо артиллерией заряд, который взрывается над землей. Образуется газовое облако, которое оседает вниз, заполняя емкости и расселины. Затем следует еще взрыв, опустившаяся масса воспламеняется. Эффект невообразимый. Все живое уничтожается. У лю- 
дей, оборонявших укрепленный пункт, лопаются барабанные перепонки, происходит сотрясение мозга, разрыв внутренних органов.

Действие генетического оружия связано с поражением определенных генов у определенных генетических групп населения. Характерно, что несколько лет назад в Китае появилась такая болезнь, как атипичная пневмо-ния. Из 8437 человек, заболевших в мире, 7960 оказались китайцами, из 813 погибших - 770 опять-таки китайцы (там же: 284). Известен такой вид генного оружия, как сибирская язва. Так, в результате его испытания еще в советское время на Урале в одном из поселков стали вымирать мужчины в возрасте от 16 до 46 лет. После террористического акта в Америке 11 сентября 2001 г. десятки людей по почте стали получать конверты с сибирской язвой, либо белым порошком, его имитирующим. На Западе (в США, прежде всего) и в России продолжаются секретные разработки поражающих средств, основанных на современных новых принципах применения. Так, в печати промелькнуло сообщение о том, что в Америке продолжается создание пси-оружия, основанного на когнитивных принципах, т. е. воздействующего на подсознание человека.

Кроме того, выявилась общемировая тенденция - будущие войны на поле боя проводить без человека, использовать боевую технику, например, танки с помощью дистанционного управления. Так, в боевой обстановке в Сирии в 2016 г. был успешно испытан танк российского производства. Оказывается, танки без экипажа, беспилотники и самоходные мины изобретены раньше, чем принято думать. Управляемые катера и самодвижущиеся механизмы появились у военных довольно давно. Разработка их началась еще в годы Первой мировой войны, а во время Второй мировой эти устройства уже широко использовались в ходе боевых действий. Свои боевые работы были и у Советского Союза, и у Соединенных Штатов, больше других в их создании преуспели инженеры Третьего рейха. Например, робот - бомбардировщик был изобретен в Германии. «Фау-1», «Оружие возмездия», стал прообразом первой в мире крылатой ракеты. К концу войны здесь создавались роботы-субмарины, роботы-тральщики. На базе «Рамы» - самолета-разведчика строился первый беспилотник. Все эти наработки после войны попали за океан, что обеспечило американцам приоритет в строительстве подобных систем (Филин, 2016).

Тезис девятый - «Россия - осажденный лагерь».В современной литературе часто встречается утверждение, что указанное определение принадлежит Сталину. В самом деле, впервые использовал данное словосочетание известный российский историк Н. М. Карамзин. Современная ситуация отчасти попадает под это определение: Россия оказалась фактически без союзников. НАТО придвинулась к нашим западным рубежам. Это представляет реальную угрозу национальной безопасности. Бывшие 
наши союзники - Польша и прибалтийские государства предоставляют Североатлантическому блоку, ведомому США, которые вносят 75\% в бюджет этого военного политического союза, неограниченные возможности для развертывания систем ПРО. Известно, что подполетное время ракет средней дальности 5-6 минут. Это заставило военно-политическое руководство России предпринять экстренные (затратные) меры. Так, выступая в апреле 2016 г. перед Конгрессом США, командующий силами НАТО в Европе генерал Бридлав назвал Калининград - наш западный форпост «полностью закрытым пузырем», непроницаемым для любых атак с воздуха, земли или моря. В последнее время Москва вооружила этот регион, как говорится, до зубов, оснастив базы современными противовоздушными комплексами C-400 и мобильными противокорабельными ракетными комплексами «Бастион». Прошли и учения по развертыванию «Искандеров» (Калининград ..., 2016).

Примечательно, что в стране начало формироваться оборонное сознание, повысился как никогда после распада СССР престиж Вооруженных сил. Конкурсы в военные академии и училища возросли в несколько раз. Зафиксирован рост национального сознания российских граждан. Этому в значительной степени способствовали, как сказали бы социологи, реперные явления: Олимпиада в Сочи, присоединение Крыма («крымнаш»), борьба с международными террористами в Сирии. Весной 2016 г. в Московском центре Карнеги произошла презентация материалов Центра на тему: «Хотят ли русские войны. Война и террор в восприятии россиян эпохи осажденной крепости». Аналитики исходили из того, что значение войны для российского массового сознания трудно переоценить, потому как память о Великой Отечественной войне всегда была и остается основой единства нации. Оказалось, что восприятие войны россиянами с советских лет практически не изменилось. Поэтому сегодняшняя война, равно как и вчерашняя, является по отдельности или одновременно холодной, горячей, информационной, торговой и т. д. Военные операции России для ее граждан является справедливой, оборонительной, победоносной, триумфальной, превентивной. Война с террором дополняет «благородный» облик оборонных усилий сегодняшней власти. Несмотря на всю противоречивость и парадоксальность мышления, россияне не хотят настоящей войны, то есть государств - с государствами, ядерной. Массовое сознание российских граждан характеризуется «стабильностью» и радостью за вновь обретенное чувство статуса великой державы и ее военной и геополитической мощью (Юрьев, 2016).

Исследования, проведенные ВЦИОМ в 2016 г., показывают, что тревога из-за международных конфликтов у россиян выросла по сравнению с 2015 г. в два раза и стоит на первом месте. Второе место в рейтинге тре- 
вожности занимает подорожание привычных товаров или вовсе их исчезновение из продажи (Петин, 2016).

Нельзя не обратить внимание на позицию, которую изложил авторитетный ученый, профессор Александр Пыжиков в интервью еженедельнику «Аргументы недели». На вопрос «Кого будем защищать в третью мировую?» он ответил, что за «нынешнее вновь выстроенное сословное общество люди воевать, а тем более отдавать жизни не будут». К сожалению, наша воровская элита «не в состоянии понять, что Родина для нас это не деньги «на кармане», а нечто другое - гораздо более важное.<...> Если российский люд не будет воспринимать людей во власти как своих плоть от плоти, то, боюсь, отражение какой-либо агрессии пойдет по другому сценарию. Не тому, как видится VIP-персонам, гарцующим с георгиевскими лентами на телевизионных экранах» (Пыжиков, 2016: 3).

Человечество (вернее, ведущие страны) договорилось о запрещении оружия массового поражения, как-то: химическое и биологическое.Попрежнему остается актуальным вопрос о запрещении ядерного оружия. Это оружие, несмотря на известные усилия США, России, Великобритании, ФранцииКитая, обладающие ядерным потенциалом, расползается по миру. Обходят молчанием Индия, Пакистан и Израиль. А вот КНДР, наоборот, проводит его испытания, а также ракетной техники изаявляет об этом открыто, несмотря на санкции ООН. Что может спровоцировать третью мировую войну.

В связи с обострением международной обстановки в Военной доктрине РФ появилось напоминание, что в случае угрозы национальной безопасности страны, Россия может нанести превентивный удар по вероятному противнику (это сделано по образу и подобию документа, принятого ранее в США). Вспоминается, что в разгар холодной войны в СССР разрабатывался план возмездия при обмене ядерными ударами между двумя сверхдержавами. Гипотетически предполагалось, когда будут уничтожены штабы и центры управления страной, то под влиянием повышения температуры в атмосфере в горах раскроются секретные ракетные шахты, из которых в автоматическом режиме будут выпущены баллистические ракеты, запрограммированные на Вашингтон и ядерные базы Америки.

Следует подчеркнуть, что стратегический расчет высших военнополитических кругов имеет серьезное основание. Военный бюджет современной России в 10 раз меньше, чем в США. Он в 2016 г. составил около трех триллионов рублей. При этом от четверти до трети военного бюджета тратится именно на ядерные разработки. И это не случайно. Стратегические ядерные силы России, как и США, обветшали. У большинства систем выработаны гарантийные сроки. Кроме того, потеряна кооперация с Украиной по тяжелым баллистическим ракетам. На обновление ядерных 
сил американцы заложили триллион долларов. Поэтому даже в условиях кризиса, Россия вынуждена тратить большие деньги на совершенствование ядерного потенциала, чтобы поддерживать ядерный паритет с США, что придает стране вес на международной арене.

Вопреки официальным заявлениям о том, что Россия не дает втянуть себя в гонку вооружений, все происходит наоборот. «Государство уже втягивается в масштабное военное соперничество, - считает руководитель Центра международной безопасности ИМЭМО РАН, академик РАН А.Г.Арбатов, - прежде всего с США, причем новая гонка вооружений может оказаться более сложной, затратной и опасной, чем гонка вооружений времен холодной войны» (Арбатов, 2016: 13).

Для справки: в СССР расходы на оборону составляли 25\% бюджета страны. Советский союз содержал, помимо своей, 40 армий мира (все армии соцстран, а также государств так называемой социалистической ориентации).

Что касается обычных вооружений, то по ряду параметров Россия проигрывает США, за исключением по танкам, самоходным орудиям. Представление дает следующая таблица 1.

Таблица 1. Сравнение единицы вооружения США и Россия

\begin{tabular}{|c|c|c|}
\hline США & Параметр & Россия \\
\hline 1430000 & $\begin{array}{c}\text { Кадров на действительной во- } \\
\text { енной службе }\end{array}$ & 766000 \\
\hline 13683 & Всего самолетов & 3082 \\
\hline 6012 & Всего вертолетов & 973 \\
\hline 8325 & Всего танков & 5500 \\
\hline 1534 & Всего самоходных орудий & 3990 \\
\hline 1930 & Всего РСЗО & 7 \\
\hline 24 & Основных портов и термина- \\
& лов & 352 \\
\hline 473 & Всего кораблей ВМС & 1 \\
\hline 10 & Авианосцев & 43 \\
\hline 72 & Единиц подводного флота & 74 \\
\hline 15 & Фрегатов & 34 \\
\hline 0 & Корветов & Миноносцев \\
\hline 13 & &
\end{tabular}

(Справка «Криминала», 2016).

Исходя из своего потенциала, Россия сосредотачивает внимание на разработке перспективных как наступательных, так оборонительных систем, как ответ на американские планы «Быстрого глобального удара» 
(БГУ). Минобороны РФ приступило, в частности, к развертыванию нового поколения ракет дальнего радиуса действия, которые имеют четыре миниатюрные ядерные боеголовки. Помимо этого в разработке находятся пять видов межконтинентальных баллистических ракет и новый боевой железнодорожный ракетный комплекс (Степанов, 2016).

Недавно в России состоялось очередное успешное испытание нового маневрирующего боевого оснащения для тяжелой межконтинентальной баллистической ракеты (МБР) «Сармат». Ракета, сброшенная с бомбардировщика В-52, успешно пролетела 426 км над океаном на скорости, превышающей пять звуковых. Данное гиперзвуковое оружие может взломать любую ПРО. Примечательно, что американцы первыми начали разработку этого вида оружия. Ожидается, их сверхзвуковая ракета будет готова не раньше 2020-х годов (Вяткин, 2016).

К этому времени будет отработана система C-500, способная сбивать гиперзвуковые ракеты и низкоорбитальные спутники (там же). Ответом на наращивание сил НАТО в непосредственной близости от наших границ явилось создание к концу 2016 г. в Российской армии трех новых дивизий: двух в Западном военном округе и одной - Южном.

Тезис десятый - резюме. Подводя итоги сказанному, следует подчеркнуть, что войны в истории человечества велись как «дикими», варварскими, так и цивилизованными народами. Велись они, как правило, за территории, «жизненное пространство». B XVII-XIX вв. в России они происходили через каждые два-три года. Завоевателей привлекали, с одной стороны богатые ресурсы, с другой стороны - отсутствие на ее границе естественных барьеров (гор, морей, особенно на западных рубежах). В отличие от Северной Америки, которая могла «отсидеться» за океаном. В наше время, в условиях глобализации, когда расширился арсенал экономических, политических и психологических средств выкачивания природных ресурсов, целью войны перестала быть оккупация территории противника.

Как раньше, так и теперь правители государств, военно-политическая и экономическая элита втягивают свои народы в большие и малые войны, которые развиваются по своим законам. Пожар войны, если он начался, как показывает история, трудно погасить. Спусковым крючком нынемогут быть даже неспровоцированные действия противостоящих сторон.

Глобализация как мейнстрим мирового развития, как переход индустриального общества в постиндустриальное, информационное, когда грядет высокоиндустриальный прорыв, создается шестой технологический уклад, в основе которого информация, биотехнологии, создание новых материалов, безусловно, снижают роль государства, по отнюдь не уничтожает. Национальное государство переживает трансформацию, но 
сохраняет «качества и блага суверенного правового сообщества» (А. Неклесса) (есть государственные органы, силовые структуры, таможни и т.д.). Только государство как легитимный институт может посылать людей на смерть, вершить суд над человеческими судьбами. Уничтожение государства как организационно-правовой системы, которая сдерживает людей от самосуда, «войны всех против всех», недопустимо. Но нельзя не заметить, что функции государства изменяются, и это касается, прежде всего, национальной безопасности.

В связи с тем, что войны становятся гибридными, государство должно учитывать, что возникли инновационные формы политической организации: мировые регулирующие органы, различного рода субсидиарные автономии и сепаратистские образования, геоэкономические интеграции, государства - корпорации; что следует уделять значительное внимание опережающим разработкам, а также приспосабливать гражданские технологии к военному делу, в том числе высоких гуманитарных технологий - "highhume" (Неклесса, 2016).

О том, что правила война существенно изменились и идут они не по шаблону, говорит начальник Генерального штаба Валерий Герасимов: «Возросла роль невоенных способов в достижении политических и стратегических целей, которые в ряде случаев по своей эффективности значительно превзошли силу оружия. Акцент используемых методов противоборства смещается в сторону широкого применения политических, экономических, информационных, гуманитарных и других невоенных мер, реализуемых с задействованием протестного потенциала населения. Все этодополняется военными мерами скрытого характера...» (там же).

\section{СПИСОК ЛИТЕРАТУРЫ}

Арбатов, А. (2016) Россия и гонка вооружений // НГ-сценарии. 26 апреля. С. 13.

Бабиченко, К. Н. (2016) Война правами человека // Свободная мысль. № 1. С. $5-18$.

Бернацкий, А. С. (2015) Сто великих угроз цивилизации. М. : Вече.

Верлина, Ю. (2003) Россия как «главный коллектив», страдающий мазохизмом, нарциссизмом и параноидальность. Рец. на книгу ДаниэлРанкурЛаферьер. Россия глазами американского психоаналитика: В поисках научной идентичности / пер. с англ. А.П. Кузьменкова, научн. ред. В. М. Лейбин. М. : Ладомир, 2003. 288 с. // НГ EXLIBRIS. 10 июля. С. 7.

Война [Электронный ресурс] // Википедия - свободная энциклопедия. URL: https://ru.wikipedia.orq/wiki/\%D0\%92\%D0\%BE\%D0\%B9\% D0\%BD\%D0\%B0 (дата обращения: 23.04.2016).

Война образов [Электронный ресурс] // News.2. Культура. URL: news2. 
ru/story/408862 (дата обращения: 23.04.2016).

Вяткин Я. (2016) Гиперзвуковое оружие: США не помогли даже пришельцы // Аргументы недели. № 16. С. 12.

Гибридная война. Передача «Обретение смыслов». Выпуск № 134 [Электронный ресурс] // Центр Сулакшина. http://rusrand.ru/tv/meaning/ gibridnaja-vojna (дата обращения: 23.04.2016).

Гибридные войны [Электронный ресурс] // Википедия - свободная энциклопедия https://ru.wikipedia/orq/wiki/\%D0\%93\% D0\%B8\%D0 \%B1\%D1\%80\%D0\%B8D0\%B4\%D0\%BD\%D0\%B0\%D1\%8F_\%D0\%B2\%D0\% BE\%D0\%B9\%D0\%B1/4\%(дата обращения: 23.04.2016).

Идет война холодная (2015) / под ред. И. М. Ильинского. М. : Изд-во МосГУ.

Генерал Франк ванКаппен: Путин ведет в Украине гибридную войну [Электронный ресурс] //Хвиля. URL: http://hvylya.net/interview/ geopolitics2/general-frank-van-kappen-putin-vedet-v-ukraine-gibridnuyuvoynu.html (дата обращения: 23.04.2016).

Калининград превратился в непроницаемый для НАТО «пузырь» (2016) // Аргументы недели. № 15. С. 32.

Сергей Кара-Мурза. Комментарий из 2001 г. Разрушение образа Великой Отечественной войны как операция холодной войны против СССР [Электронный ресурс] //Механизмы войны. URL: http://www.warmech.ru/ war_mech/karamurza2.html (дата обращения: 23.04.2016).

Клаузевиц, К. фон (2002). О войне : в 2-х т. М. : Изд-во «АСТ» ; СПб. : TerraFantastika. T. 1.

Мирютин, Д. (2015) Путин всемогущий в зеркале фольклора // Секретные материалы. № 23. С. 3.

Мутагиров, Д. 3. (2016) Миф о конце «холодной войны» // Свободная мысль.№ 1 . С. 13-32.

Неклесса, А. (2016) Смысл слов. Государство, безопасность, война, вооруженные силы - все эти понятия отстают от реальности // Независимая газета. 2016. 16 марта. С. 5.

Ожегов, С. И. (1982) Словарь русского языка / под ред. Н. Ю. Шведова. Изд. 14-ое, стереот. М. : Русский язык.

Петин, В. (2016) 30 пунктов для беспокойства // Российская газета. 2016. 20 января. С. 7.

Пыжиков, А. (2016) «Кого будем защищать в третьей мировой?» // Аргументы недели. 2016. № 17. С. 3.

Совещание послов и постоянных представителей России (2012) [Электронный ресурс] // Президент России. 12 июля. URL: http://www.kremlin. ru/events/president/news/15902 (дата обращения: 12.12.2015).

Справка «Криминала» (2016) // Криминал. № 17. С. 9.

Степанов, А. (2016) Вышли на старт. В мире началась новая гонка 
ядерных вооружений // Наша версия. № 16. С. 10.

Филин, Г. (2016) Боевые роботы Адольфа Гитлера // Наша версия. №13. C. 14 .

Фромм, Э. (2004) Анатомиячеловеческойдеструктивности / пер. с нем. Э. Телятниковой. М. : ООО Изд-во «АСТ».

Юрьев, Г. (2016) Мифология весной войны // НГ - сценарии. 26 апреля. Дата поступления: 15.06.2016 2.

Королев Анатолий Акимович - доктор исторических наук, профессор, профессор кафедры истории Московского гуманитарного университета, заслуженный деятель науки Российской Федерации. Адрес: 111395, Россия, г. Москва, ул. Юности, д. 5. Тел.: +7 (499) 374-55-81. Эл.адрес: anatoliy-korolev@rambler.ru

Korolev Anatoly Akimovich, Doctor of History, Professor, Department of History, Moscow University for the Humanities; Honoured Scientist of the Russian Federation. Postal address: 5 Yunosti St., 111395 Moscow, Russian Federation. Tel.: +7 (499) 374-55-81. E-mail: anatoliy-korolev@rambler.ru 